\title{
UJI SENSITIFITAS SARI BUAH PARE (Momordica charantia L) PADA BAKTERI Edwardsiella tarda DENGAN METODE DIFUSI KERTAS CAKRAM SECARA IN VITRO
}

\section{SENSITIVITY TEST OF FRUIT BITTER MELON JUICE (Momordica charantia L) ON BACTERIA Edwardsiella tarda WITH PAPER DISC DIFFUSION METHOD IN VITRO}

\author{
Sudarno, Selvi Lely Rosanti dan Sri Subekti \\ Fakultas Perikanan dan Kelautan Universitas Airlangga \\ Kampus C Mulyorejo - Surabaya, 60115 Telp. 031-5911451
}

\begin{abstract}
One of the problems encountered in fish farming is the disease attack. The attack of disease that was caused by bacteria is a problem that often occur in aquaculture. Traditional medicine is more readily accepted by communities because is cheap and easily available, have been quite familiar with the community. There were various kind of traditional medicine and has been widely studied chemically content and usefulness. Therefore there were still many plants unknown levels of toxicity, therefore need further study.

Bacteria E. tarda spread in some countries such as Europe, Japan, Taiwan, Thailand, United States, Singapore, and Malaysia. While in Indonesia E. tarda were found in Java, Sumatra, and Borneo.

The aim of the research is to know the capabilities of the inhibition zone of fruit bitter melon power against the bacteria $E$. tarda in vitro and knowing whether fruit bitter melon effective in inhibiting the growth of the bacteria $E$. tarda with gold standard comparator antibiotics Tetracycline.

The research was conducted on February 2011 in Bacteriology and Microbiology, laboratory in Fish Quarantine Juanda Sidoarjo district of East Java. The method used in this research is descriptive method that was done in vitro by using sensitivity test of diffusion method with the determination of inhibition zone by comparing with antibiotic inhibition zones.

The results showed that bitter melon juice has a bacterial growth inhibition against E. tarda, although when was compared with gold standard antibiotic tetracycline shared considered less sensitive. Observations showed clear zone of bitter melon fruit juice shared with a diameter of $13.3 \mathrm{~mm}$, was compared with standard antibiotic tetracycline can inhibit with a minimum diameter of $15 \mathrm{~mm}$. Sensitivity test of bitter melon fruit juice will be classified as not susceptible to the bacteria therefore is able to inhibit E. tarda.
\end{abstract}

Keywords : Edwardsiella tarda, Momordica charantia L., Antibiotic Tetracycline

\section{Pendahuluan}

Salah satu kendala yang sering dihadapi dalam budidaya ikan adalah serangan penyakit. Serangan penyakit yang disebabkan oleh bakteri merupakan suatu kendala yang sering terjadi dalam budidaya perikanan. Masyarakat Indonesia telah lama mengenal serta menggunakan obat-obatan alami atau yang dikenal dengan obat tradisional. Obat tradisional lebih mudah diterima oleh masyarakat karena selain murah dan mudah didapat,telah cukup akrab dengan masyarakat. Terdapat berbagai macam obat tradisional yang berasal dari tanaman dan telah banyak diteliti kandungan kimia dan khasiat yang berada di dalamnya. Namun masih banyak tanaman yang belum diketahui kadar toksisitasnya, sehingga perlu diteliti lebih lanjut (Hyeronimus, 2006).

Buah Pare mudah sekali didapatkan hampir di seluruh Indonesia. Masyarakat
Indonesia telah sejak lama menggunakan buah pare sebagai hidangan sehari-hari dan juga telah lama dipercaya dan dipergunakan sebagai obat tradisional untuk mengobati berbagai macam penyakit. Hal inilah yang mengundang banyak penelitian mengenai buah pare mulai dari kandungan kimia yang ada didalamnya sampai manfaat atau khasiat yang dapat diperoleh dari buah pare itu sendiri (Subahar, 2004).

Senyawa yang terdapat dalam buah pare ( $M$. charantia L.) meliputi : alkaloid, flavonoid, polifenol, steroid/triterpenoid (Chan, et al., 1984; Rivera, 1941). Mekanisme aktivitas biologis oleh senyawa flavonoid pada pare berbeda dengan yang dilakukan oleh senyawa alkaloid, dimana senyawa flavonoid dalam merusak sel bakteri memanfaatkan perbedaan kepolaran antara lipid penyusun sel bakteri dengan gugus alkohol pada senyawa flavonoid. Sedangkan pada senyawa alkaloid 
memanfaatkan sifat reaktif gugus basa pada senyawa alkaloid untuk bereaksi dengan gugus asam amino pada sel bakteri E. tarda (Robinson, 1995).

E. tarda merupakan penyebab penyakit bakteri yang paling serius pada budidaya ikan sidat di Taiwan dan Jepang, sedangkan $E$. ictaluri pada akhir tahun 1980 dilaporkan telah menyebabkan kernatian masal (lebih dari 50\%) anak ikan dan induk ikan lele Amerika di AS. Kerugian yang ditimbulkan mencapai puluhan juta dolar atau puluhan milyar rupiah. Beberapa sampel yang ditemukan pada saat dilakukan pemantauan HPIK menunjukkan haemorrhage pada beberapa bagian permukaan tubuh dan sirip dari sampel-sampel yang sakit. Dari hasil pemeriksaan sampel pemantauan HPIK diketahui bahwa sampel terserang bakteri $E$. tarda (Karantina Ikan, 2007).

Tujuan dari penelitian ini adalah mengetahui kemampuan zona hambat daya Sari Buah Pare terhadap bakteri E. tarda secara in vitro dan mengetahui apakah Sari Buah Pare efektif dalam menghambat pertumbuhan bakteri E. tarda dengan standar pembanding antibiotik Tetracycline.

Penelitian ini diharapkan dapat memberikan informasi tentang kemampuan Sari Buah Pare dalam menghambat bakteri E. tarda secara in vitro.

\section{Metodologi}

Penelitian dilakukan di Laboratorium Bakteriologi Balai Karantina Ikan Juanda kecamatan Semambung kabupaten Sidoarjo Jawa Timur pada bulan Februari 2011. Bahan yang digunakan dalam penelitian adalah buah pare gajih yang diperoleh dari pasar-pasar Tradisional atau Swalayan, bakteri Edwardsiella tarda yang diperoleh dari Balai Karantina Ikan Juanda, aquades steril, Trypticase Soya Agar (TSA), kertas saring, kertas cakram, Antibiotik Tetracycline $30 \mu \mathrm{m}$, bahan untuk uji biokimia (TSIA, urea, simmons citrate agar, O/F, MR/VP, gula-gula, LIA). Alat yang digunakan dalam penelitian ini adalah tabung erlenmeyer, petri dish, tabung reaksi, cawan petri, rak, mikropipet, paper disk, jarum ose, Spatel bengkok, inkubator, autoclave, pembakar bunsen, kapas, dan blender, corong dan vortex, mikroskop, object glass, penggaris.

Prosedur kerja dari penelitian ini yaitu melakukan persiapan alat dan bahan untuk kemudian di sterilisasi, kemudian mempersiapkan larutan sari buah pare (Momordica charantia L.) dengan berbagai konsentrasi dan tiap-tiap konsentrasi dimasukkan paper disk untuk direndam sampai jenuh. Setelah itu mempersiapkan suspensi bakteri E. tarda yang telah disetarakan dengan kepadatan bakteri $10^{8} \mathrm{CFU} / \mathrm{ml}$ dan ditanam pada media TSA (Tryptone Soy Agar) sebanyak 0,2 ml. Kemudian paper disk ditempelkan pada media dan sebagai kontrol pada media ditempelkan antibiotika disk Tetracycline $30 \mu \mathrm{g}$. Setelah itu diinkubasi dan diukur diameter zona hambat yang terbentuk untuk kemudian dibandingkan dengan standar umum antibiotika Tetracycline $30 \mu \mathrm{g}$.

\section{Hasil dan Pembahasan}

Identifikasi bakteri dilakukan untuk memastikan suatu kebenaran bakteri E. tarda yang diperoleh dari Balai Karantina Ikan Juanda. Metode yang digunakan untuk identifikasi bakteri yaitu, melalui pengamatan morfologi koloni bakteri dan pengamatan secara mikroskopik menggunakan pewarnaan gram serta pengujian sifat biokimia dari bakteri $E$. tarda.

Pada penelitian ini hasil penentuan zona hambat yang diperoleh bahwa sari buah pare (Momordica charantia L) mempunyai aktivitas menghambat pertumbuhan bakteri $E$. tarda dilakukan dengan cara mengukur besarnya zona terang dengan menggunakan penggaris. Menurut Wibowo (2002), pengukuran zona hambat dilakukan dengan cara mengukur secara garis lurus tengah zona hambat (diukur dari tepi sampai tepi zona hambat yang terbentuk).

Hasil penelitian menunjukkan bahwa sari buah pare (Momordica charantia L) mempunyai daya hambat terhadap petumbuhan bakteri $E$. tarda tetapi jika dibandingkan dengan standar antibiotika tetracycline $30 \mu \mathrm{m}$ masih dikategorikan kurang peka. Hasil pengamatan zona terang menunjukan sari buah pare hanya mampu menghambat dengan diameter 13,3 $\mathrm{mm}$. Hal ini disebabkan sebagai pembanding standar antibiotika tetracycline mampu menghambat dengan minimal diameter $15 \mathrm{~mm}$. Uji sensitifitas sari buah pare tergolong tidak peka akan tetapi mampu menghambat terhadap bakteri E. tarda dikarenakan, sari buah pare yang terdapat kandungan antibakteri itu sendiri berbeda dengan ekstrak.

Uji sensitifitas sari buah pare tergolong tidak peka akan tetapi mampu menghambat terhadap bakteri E. tarda hasil pegamatan zona terang menunjukakn sari buah pare hanya mampu menghambat dengan diameter $13,3 \mathrm{~mm}$, pembanding antibiotik Tetracycline $30 \mu \mathrm{m}$ mampu menghambat dengan diameter $15 \mathrm{~mm}$. Sari buah pare yang terdapat kandungan antibakteri itu sendiri berbeda dengan ekstrak, 
kemungkinan pada saat di blender kandungan antibakteri yang terdapat pada pare tidak dapat larut dalam air sehingga zona hambat yang didapatkan tidak cukup maksimal.

Hasil pengamatan terdapat zona hambat pada pemberian sari buah pare terhadap E. tarda tetapi tidak melebihi zona hambat antibiotika Tetracycline $30 \mu \mathrm{m}$. Oleh karena itu dalam upaya menghambat pertumbuhan bakteri diperlukan juga dengan ekstraksi sehingga kandungan antibakteri dapat diperoleh secara maksimal (Volk and Wheeler, 1993).

\section{Kesimpulan}

Sari buah pare memiliki zona hambat terhadap bakteri E. tarda. Sari buah pare memiliki zona hambat tertinggi $13,3 \mathrm{~mm}$ yang tidak melebihi antibiotik tetracycline $15 \mathrm{~mm}$.

Perlu dilakukannya penelitian lebih lanjut dengan cara ekstraksi. Sehingga bisa didapatkan hasil yang lebih maksimal dalam mendapatkan kandungan antibakteri yang diperoleh dari pare tersebut.

\section{Daftar Pustaka}

Hyeronimus SB, 2006. Ragam dan Khasiat Tanaman Obat. 1st ed. Jakarta: Agro Media;.

Karantina ikan. 2007. Laporan Pemantauan HPI/HPIK karantina ikan Batam tahun 2007. http://114.31.243.67/upt/batam/ doc/pantau2007.pdf. diakses pada tgl 2 maret 2011.

Rivera, G. 1941. Preminary Chemical and Pharmacological Studies on "cunde amor" Momordica charantia L. (I) Am. J. Pharm. 113 (7) : 281-297

Robinson, T. 1995. Kandungan tinggi bahan organik tinggi. Bandung: ITB. Hal 7172.

Subahar TS. 2004. Khasiat dan Manfaat Pare. Penerbit Agromedia Pustaka, Jakarta.

Volk, W.A., M.F. Wheeler. 1993. Mikrobiologi Dasar edisi kelima Jilid 1 Terjemahan Markham. Erlangga. Jakarta.

Wibowo, M. S. 2002. Penetapan potensi antibiotic secara mikrobiologi. School of pharmacy. ITB. Bandung. 